\title{
Natural history of Holoaden luederwaldti (Amphibia: Strabomantidae: Holoadeninae) in southeastern of Brazil
}

\author{
Itamar A. Martins \\ Laboratório de Zoologia, Universidade de Taubaté. Avenida Tiradentes 500, 12030180 Taubaté, São Paulo, Brasil. \\ Email: istama@uol.com.br
}

\begin{abstract}
This study reports the rediscovery of Holoaden luederwaldti Miranda-Ribeiro, 1920 and provides information on the distribution, sexual dimorphism, reproduction and vocalization of a population of this species in Campos do Jordão, São Paulo (southeastern Brazil). Sampling was carried out in the Parque Estadual de Campos do Jordão (PECJ) from October 2005 through December 2008. Collecting was conducted using pitfall traps with a drift-fence on different altitudinal gradients $(1,540 \mathrm{~m}, 1,780 \mathrm{~m}$ and 2,000 $\mathrm{m}$ a.s.l.). Fifty-two specimens of $H$. luederwaldti were collected in the PEC). The mean snout-vent length (SVL) was $36.17 \mathrm{~mm}$ for males and $42.61 \mathrm{~mm}$ for females, indicating sexual dimorphism in body size. Holoaden luederwaldti occurred during the warm-rainy months. The population was distributed between 1500 and $2000 \mathrm{~m}$, and the greater abundance was registered in well preserved forest areas. Mature females contained from 36 to 41 oocytes and the mean of oocyte diameter was $3.72 \mathrm{~mm}$. The advertisement call of $H$. luederwaldti consists of simple notes composed of three harmonics. The record of the population of $H$. luederwaldti in the PECJ has reinforced the importance of investigating different areas of the forest when conducting faunal surveys.
\end{abstract}

KEY WORDS. Advertisement call; Atlantic forest; fecundity; Holoaden; use of habitat.

The anuran Strabomantidae Hedges et al. (2008) contains 18 genera with 553 species, divided into two subfamilies, Strabomantinae and Holoadeninae. Holoadeninae includes six genera - Noblella Barbour, 1930, Euparkella Griffits, 1959, Bryophryne Hedges, Duellman and Heinicke, 2008, Psychophrynella Hedges, Duellman and Heinicke, 2008, Barycholos Heyer, 1969, and Holoaden Miranda-Ribeiro, 1920 with 40 species occurring in South America (Hedges et al. 2008, Frost 2009). Euparkella and Holoaden are endemic to the Atlantic Forest in southeast Brazil (Hedges et al. 2008).

Holoaden contains three species - Holoaden luederwaldti Miranda-Ribeiro, 1920, Holoaden bradei B. Lutz, 1958, and Holoaden pholeter Pombal, Siqueira, Dorigo, Vrcibradic and Rocha, 2008 - endemic to the montane Atlantic Forest (between 1,200 and 2,500 m a.s.l.) of the states of São Paulo, Minas Gerais, and Rio de Janeiro (Lutz 1958, Cruz \& Peixoto 2004, Pombal-Jr et al. 2008).Even though the first specimen of $H$. luederwaldti was collected by H. Luederwaldt in 1905 (Municipality of Campos do Jordão, state of São Paulo, southeastern Brazil; type locality, $22^{\circ} 44^{\prime} \mathrm{S}, 45^{\circ} 36^{\prime} \mathrm{W}, 1,600 \mathrm{~m}$ a.s.l.), the species was only described in 1920, by Miranda-Ribeiro. The Amphibia Collection of the Museu de Zoologia da Universidade de São Paulo houses 16 specimens collected in Campos do Jordão, state of São Paulo, up to 1967, and one specimen collected in 1953 by C. Gans from Cidade Azul, actually Campos do Jordão (PombaL-Jr et al. 2008). Therefore, more than 40 years have elapsed with no new record of $H$. luederwaldti from the type locality.
Due to uncertainties about the distribution, status and ecological requirements of $H$. luederwaldti this species was classified as "data deficient" (DD) in the List of Threatened Brazilian Fauna (HADDAD 2005), in the list of threatened wild species of the state of São Paulo (São Paulo 2008, Decreto 53.494), and in the IUCN Red List (Cruz \& Peixoto 2004) . In the Red List of the state of Rio de Janeiro (CARAMASCHI et al. 2000), H. luederwaldti is listed as "vulnerable".

HADDAD (2005) noted that many species that are presently classified as "DD" may not be really threatened. Therefore, a strong effort is necessary to evaluate the real situation of DD species in nature and expand knowledge of their distribution and habitats (HADDAD 2005) by means of intensive field studies.

This study reports on the rediscovery of a population of H. leuderwaldti in the Parque Estadual de Campos do Jordão (PECJ), municipality of Campos do Jordão, state of São Paulo, southeastern Brazil. Information about sexual dimorphism, reproductive biology, use of habitat, and vocalization is presented.

\section{MATERIAL AND METHODS}

The municipality of Campos do Jordão is located in the Serra da Mantiqueira, at a mean altitude of 1,400 $\mathrm{m}$ a.s.l. The topography is very uneven, with some peaks higher than 2,000 $\mathrm{m}$, and is cut by many streams arising from the Mantiqueira Range (Prado \& Abreu 1995). The Parque Estadual de Campos do Jordão (PECJ) $\left(22^{\circ} 39^{\prime} 30^{\prime \prime}-22^{\circ} 42^{\prime} 58^{\prime \prime}\right.$ S, $\left.45^{\circ} 26^{\prime} 32^{\prime \prime}-45^{\circ} 27^{\prime} 27^{\prime \prime} \mathrm{W}\right)$ is located in the northern part of the municipality of Campos do 
Jordão, at altitudes ranging from 1,030 to 2,007 $\mathrm{m}$. The PECJ covers an area of approximately 8,300 ha, and occupies onethird of the total area of the municipality of Campos do Jordão.

Collecting was carried out monthly in the PECJ, from October 2005 to December 2008, lasting four days on average. The sampling was conducted using lines of pitfall traps with a drift fence installed at different altitudinal gradients in three areas (spaced about $2.5 \mathrm{~km}$ ): area I at 2,000 m, area II at 1,780 $\mathrm{m}$, and area III at $1,540 \mathrm{~m}$ a.s.l. (Tropical Rainforest). On each altitudinal gradient area, three lines of pitfall traps with a $8 \mathrm{~m}$ drift-fence, containing 10 buckets (100 l), were installed, totaling 90 traps. Pitfall lines were installed with a distance of 150 $\mathrm{m}$ between each other.

All the specimens collected had their snout-vent length (SVL) measured with a caliper, to a precision of $0.01 \mathrm{~mm}$. Voucher specimens are housed in the Scientific Collection of the Laboratório de Zoologia of the Universidade de Taubaté (CCLZU), Taubaté, São Paulo; in the Célio F.B. Haddad Collection (CFBH) of the Departamento de Zoologia, Universidade Estadual Paulista, UNESP, Rio Claro, São Paulo; and in the Museu de Zoologia da Universidade de São Paulo (MZUSP).

The vocalization of $H$. luederwaldti was recorded with a Marantz PMD-222 cassette recorder coupled to external semidirectional (ME 66) Sennheiser microphones. All recorded calls were edited with a sampling rate of $44,100 \mathrm{~Hz}$ and 16 bit per sample in the mono pattern. The bioacoustic analyses were performed on a computer using the program CoolEdit 96 (Syntryllium Software Corporation), with a 20,050 Hz sampling frequency. The 256 points option (Fast Fourier Transform, FFT) and, when necessary, the 1024 points option was used, mainly in determining fundamental frequencies. Five parameters of the advertisement calls were quantified: frequency bandwidth, fundamental frequency, dominant frequency, note duration, and note repetition rate. For the analyses and bioacoustic interpretations, the terms used follow MarTins \& JiM (2003).

The sex of adult specimens was determined from the snout-vent length (SVL), based on the smallest male with developed testicles. Females were determined by visual inspection, through the transparence of the ventral skin and presence of the oocytes. When necessary, abdominal incisions were made and the specimens observed by means of an optical stereomicroscope, which facilitated the confirmation of the sex. The sex of the juveniles was considered undetermined.

Females were dissected by ventral incision and had their ovaries removed. Contents of the ovaries were spread out in a Petri dish, in order to count the oocytes in each ovary. The largest diameter of the oocytes was measured, using a stereoscopic microscope with an ocular micrometer. For each dissected female, 9 to 15 oocytes were measured.

For the analyses of the abundance of specimens sampled per month in relation to the abiotic factors (total rainfall in the study months and maximum and minimum air temperature) a linear regression was used with a significance level of
5\% (ZAR 1999). The parametric t-test was used for the analyses of sexual dimorphism between females and males.

\section{RESULTS}

I sampled 52 specimens of $H$. luederwaldti: 33 males, 11 females, and 8 juveniles (undetermined). The mean of SVL of the specimens were: males $36.17 \pm 2.42 \mathrm{~mm}(31.02-40.48 \mathrm{~mm})$, females $42.61 \pm 2.48 \mathrm{~mm}$ (39.37-46.53 $\mathrm{mm})$, and juveniles 26.76 $\pm 1.43 \mathrm{~mm}(23.97-28.55 \mathrm{~mm})$. The mean of SVL of females was bigger than males $(t=6.46 ; 1 \mathrm{df} ; \mathrm{p}<0.0001)$, indicating sexual dimorphism in size (Fig. 1). No other sexually dimorphic characters, even in color patterns or morphological structures (Figs 2-4) were observed.

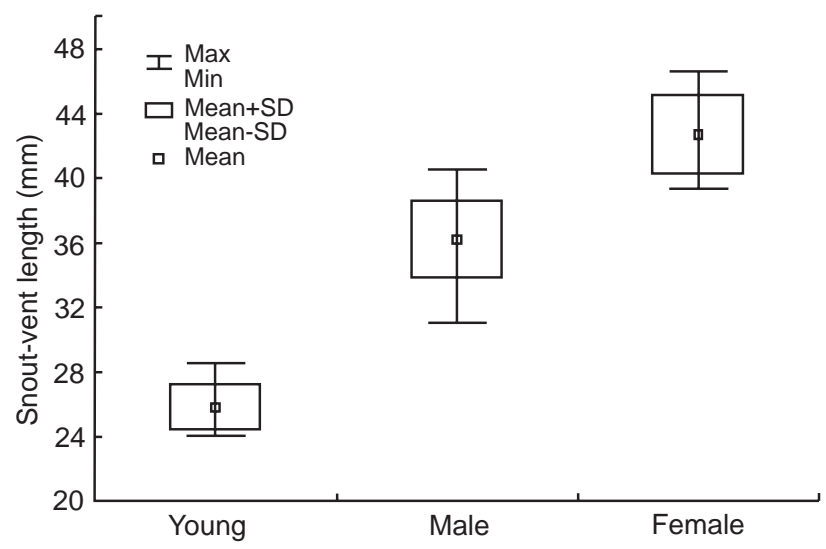

Figure 1. Snout-vent length (SVL) of juvenile and adult male and female specimens of $H$. luederwaldti recorded in the Parque Estadual de Campos do Jordão, state of São Paulo, southeastern Brazil.

Females with mature oocytes were observed in October of 2005, 2006, and 2007, and in February and April of 2008. The number of oocytes in the females varied between 36 and 41 oocytes $(37.4 \pm 3.57, \mathrm{n}=5)$. The oocytes are large and unpigmented (Fig. 5). The mean diameter of the oocytes was 3.72 $\pm 0.8 \mathrm{~mm}(2.86-4.32 \mathrm{~mm}, \mathrm{n}=96)$. The oocytes were light yellow, with a large quantity of vitelline (Fig. 5). A positive correlation was observed between the number and diameter of oocytes (Spearman's correlation, $r_{s}=0.95, p=0.013$ ) (Fig. 6). There was no correlation between the SVL of the females and the number of oocytes $\left(r_{s}=0.35, p=0.552\right)$, or the diameter of the oocytes $\left(r_{s}=0.16, p=0.79\right)$. Females with mature oocytes also had some smaller oocytes in the initial stages of development.

Holoaden luederwaldti was registered in the rainy season (Fig. 7), however there was no linear relationship between the number of specimens sampled and the pluviosity $\left(\mathrm{r}^{2}=0.001\right.$, $\mathrm{F}=0.04, \mathrm{p}=0.83$ ). The abundance was slightly associated with the maximum temperature $\left(\mathrm{r}^{2}=0.12, \mathrm{~F}=5.0, \mathrm{p}=0.03\right)$ but not 


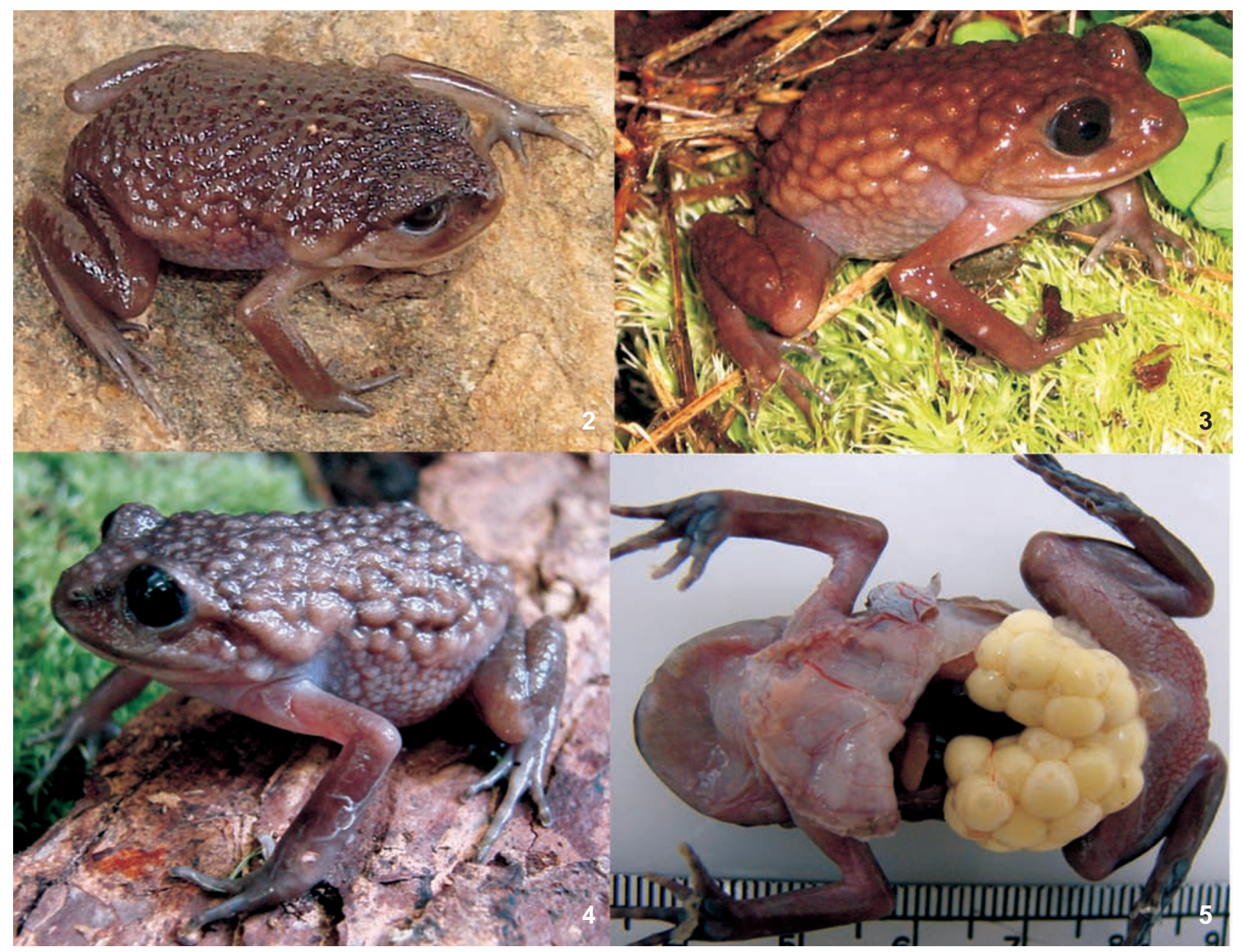

Figures 2-5. Images of specimens: (2) juvenile (3) male (4) female of $H$. luederwaldti registered in the Parque Estadual de Campos do Jordão, and (5) Coloration of oocytes.

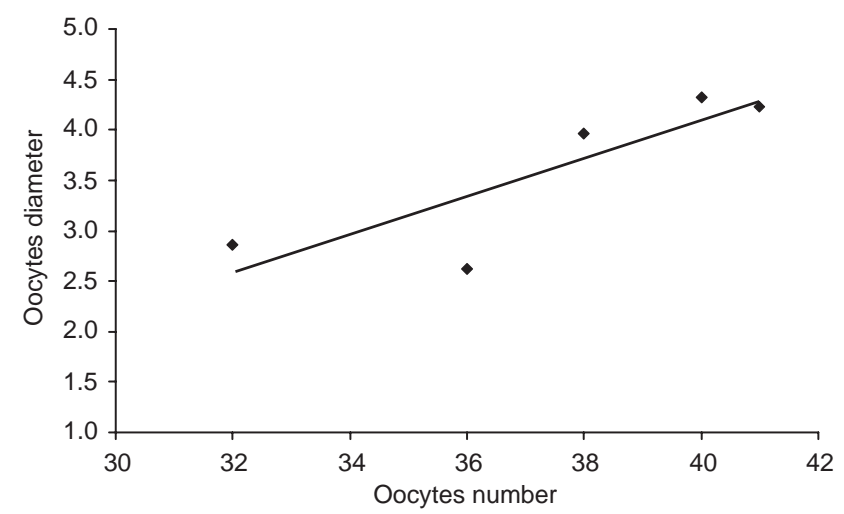

Figure 6. Relationship between the number and diameter of oocytes $(\mathrm{mm})$ of females of $H$. luederwaldti recorded in the Parque Estadual de Campos do Jordão. with the minimum temperature $\left(\mathrm{r}^{2}=0.04, \mathrm{~F}=1.55, \mathrm{p}=0.21\right)$. The highest abundances of specimens were recorded in the beginning of the warm-rainy season in October 2005 ( $n=11$ ), 2006 ( $n=10)$, and 2007 ( $n=13)$, and also at the end of the season in April $2008(n=5)$. The record of specimens at the end of the warm-rainy season revealed that there was still breeding activity, because three adult males and two females with well-developed oocytes were collected at that time.

In the Parque Estadual de Campos do Jordão, $H$. luederwaldti was distributed between the altitudinal gradient of 1,500 and 2,000 $\mathrm{m}$ a.s.l., and was found in all three sampled areas. The species was collected in greater abundance in areas II $(n=32)$ and I $(n=13)$, where the status of forest preservation is better, principally in area II, which lies in a depression between two hills, making it more difficult to access and therefore more difficult to impact by deforestation. The area III is

ZOOLOGIA 27 (1): 40-46, February, 2010 


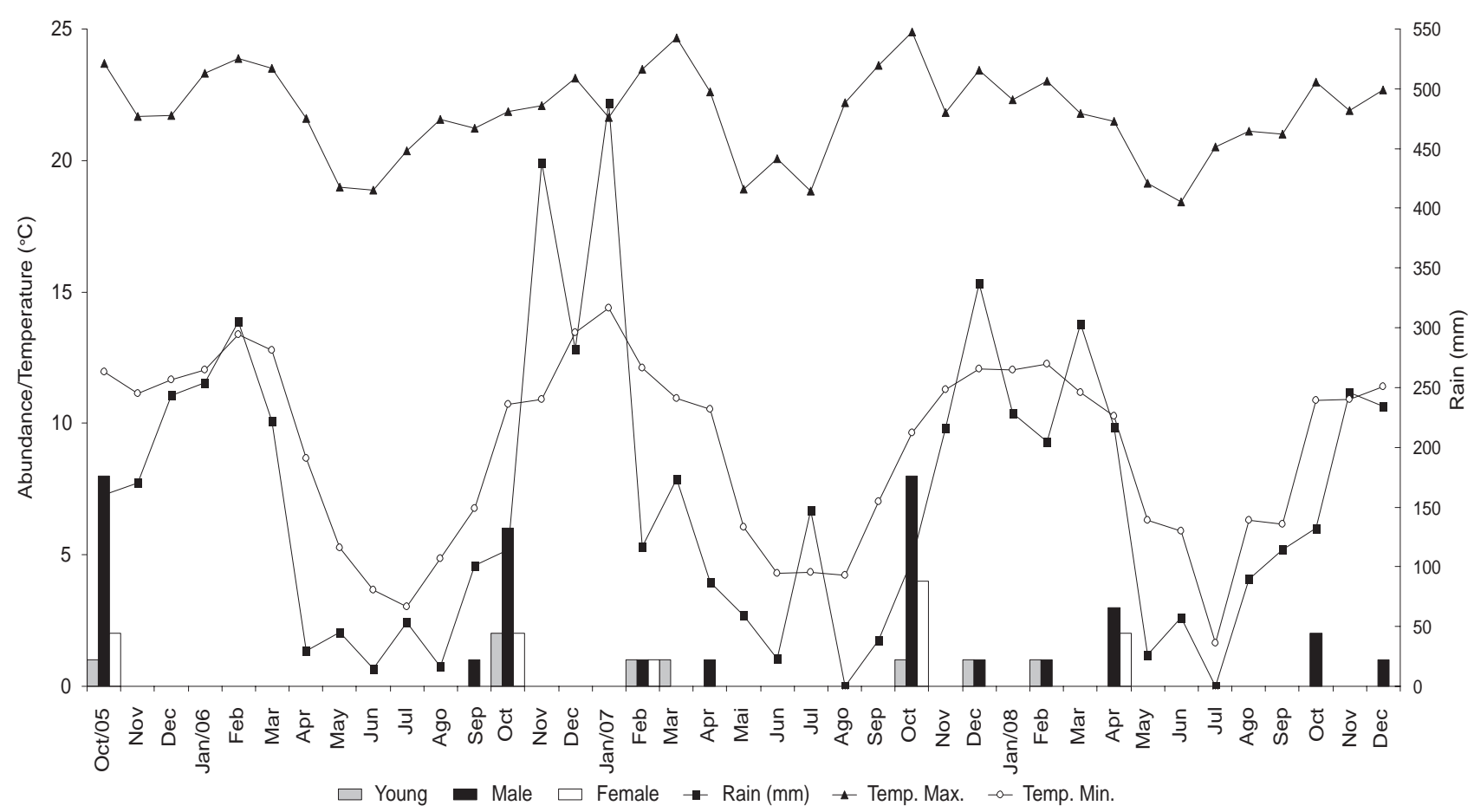

Figure 7. Abundance and temporal distribution of juveniles, males, and females of $H$. luederwaldti, and the maximum and minimum air temperature and total rainfall in the study months, recorded in the Parque Estadual de Campos do Jordão.

composed of a disturbed secondary forest and the smallest number of individuals $(\mathrm{n}=7)$ was recorded in this location.

In October 2005 and 2007 and April 2008, the calls of the collected individuals of $H$. luederwaldti $(\mathrm{n}=4)$ which had been kept in plastic bags and in aquaria, were recorded in the field. The advertisement call of $H$. luederwaldti consists of simple notes composed by three harmonics $(\mathrm{H})$ with a mean frequency range from 936 to $6244 \mathrm{~Hz}$ (Figs 8 and 9). The mean frequency ranges of the first harmonic (H1) (minimum and maximum frequencies) is between $936-1377 \mathrm{~Hz}(863-1455 \mathrm{~Hz})$, with a mean dominant frequency (DF) of $1186 \pm 31 \mathrm{~Hz}$ (1151-1256 $\mathrm{Hz}$ ). Most of the energy of these notes is concentrated in the first-order harmonic (fundamental frequency $=\mathrm{H} 1$ ). The second harmonic (H2) shows minimum and maximum frequencies between $3247-3804 \pm 94.8 \mathrm{~Hz}(3157-3995 \mathrm{~Hz})$ and $\mathrm{DF}=$ $3557 \pm 62 \mathrm{~Hz}(3428-3675 \mathrm{~Hz})$. The third harmonic (H3) shows mean frequencies between $5626-6244 \mathrm{~Hz}(5475-6462 \mathrm{~Hz})$ and $\mathrm{DF}=5988 \pm 83.5 \mathrm{~Hz}(5846-6166 \mathrm{~Hz})$ (Figs 8 and 9). The duration of the note is $32.6 \pm 1.9 \mathrm{~ms}(30-37 \mathrm{~ms})$ on average, with a mean repetition rate of $252 \pm 38.1$ (210-308) notes per minute.

\section{DISCUSSION}

The geographical distribution of $H$. luederwaldti is somewhat uncertain. Lutz (1958) reported a specimen of $H$. luederwaldti from the Serra da Bocaina in the state of Rio de Janeiro. Heyer et al. (1990) reported a registered specimen col- lected by A. Stanley Rand and Patricia Rand in 1963 at the Estação Ecológica da Boracéia, and ZAHER et al. (2005) registered $H$. luederwaldti in Estação Ecológica de Bananal, both in the state of São Paulo.

Specimens analyzed at the Museu de Zoologia da Universidade de São Paulo and identified as H. luederwaldti (= Holoaden sp.) which had been collected in state of São Paulo from: Paranapiacaba (Santo André), Estação Ecológica da Boracéia, Campo de Fruticultura in the Serra da Bocaina (São José do Barreiro), and the Estação Ecológica da de Bananal, displayed differences in morphological characters when compared with specimens collected from the type locality (Campos do Jordão). Pombal-Jr et al. (2008) provided a map of the geographical distribution of the species of Holoaden, and referred to the species collected in the Atlantic Forest (between Boracéia and Bananal) as Holoaden sp. The present study reaffirms the endemic distribution of $H$. luederwaldti in the Mantiqueira range, in high-elevation forests $(1,500$ to $2,200 \mathrm{~m}$ a.s.l.) from Campos do Jordão, state of São Paulo, and the Parque Nacional do Itatiaia (PNI) located in the states of Minas Gerais and Rio de Janeiro.

The sampling of specimens of $H$. luederwaldti from the PECJ provided information about the sexual dimorphism in that population. Females are bigger than the males. This information on sexual dimorphism in the snout-vent length can be used for identification of the sex of specimens belonging to 


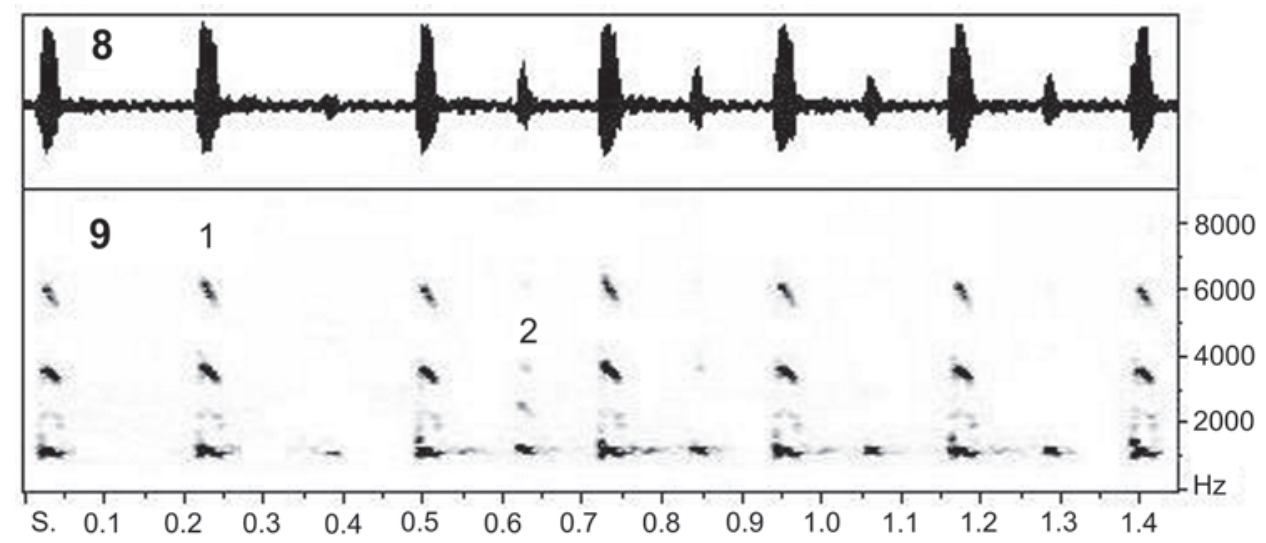

Figures 8-9. (8) Oscillogram and (9) sonogram of the advertisement call of two specimens of $H$. luederwaldti, recorded in the Parque Estadual de Campos do Jordão in October 2006 at 05:00 h, air temperature $19^{\circ} \mathrm{C}$. (1) target specimen of the recording; (2) second specimen in background.

Holoaden. Pombal-Jr et al. (2008) provided information on the body size of $H$. pholeter, the holotype being a female and the paratypes one male and one female, with body sizes of 44.6, 41.6, and 47.7 respectively. Based on the results of the present study, the females of $H$. luederwaldti are smaller (mean $=42.61$ $\mathrm{mm}, 39.37-46.53 \mathrm{~mm}$ ) than the females of $H$. pholeter.

LuTz (1958) provided snout-vent length measurements for six specimens of $H$. luederwaldti, three from the MZUSP (MZUSP 87, SVL = 39-40; MZUSP 891, SVL = 32; and MZUSP 4940$, SVL $=35 \mathrm{~mm})$, and three from the Museu Nacional do Rio de Janeiro (MNRJ) (SVL $=48,36$, and $40 \mathrm{~mm}$ ). Specimens deposited in the MZUSP were analyzed, and proved to be a female (MZUSP 87) and two males. Caramaschi \& Pombal-JR (2006) previously referred to specimen MZUSP 87 as being a female. However, the authors did not mention how the sex of this specimen was determined. The snout-vent length (SVL = $41.8 \mathrm{~mm}$ ) of MZUSP 87 differed from that given by LuTz (1958) $(\mathrm{SVL}=39-40)$. The specimens deposited in the MNRJ were not analyzed, but based on their body sizes, they appear to be two females and a male.

The presence of oocytes in different stages of vitellogenic development in $H$. luederwaldti are similar to the findings of LuTz (1958), which analyzed a female of $H$. bradei with an SVL of $33 \mathrm{~mm}$ containing 13 oocytes (eight in the right ovary and five in the left), all well developed, with large yellow yolks, 3 $\mathrm{mm}$ in diameter. The author also reported the presence of 13 additional, smaller oocytes (nine in the right ovary and four in the left), and about 30 more, undeveloped oocytes. The coloration and large quantity of vitelline in the oocytes described by Lutz (1958) are similar to the features shown by $H$. luederwaldti in this study.

Holoaden luederwaldti deposits its eggs under the leaf litter, and they have direct development (mode 23, sensu HADDAD $\&$ PRADo 2005). Females with developed oocytes were recorded in the beginning and at the end of the warm rainy period. These results suggest two hypotheses: 1) females of $H$. luederwaldti have the capacity to deposit eggs more than once during the breeding season, or 2) the observations indicate the delayed entry into the population of recently matured females, which use the end of the breeding season to deposit their eggs (WelLs 2007). Based on the analyses of the oocytes in different stages of vitellogenic development (October of 2005, 2006, and 2007) and the body sizes of the females (CRC $=40.9,43.62$, and $46.53 \mathrm{~mm}$ ) recorded at the end of the breeding season (February and April), hypothesis 1 which predicts that females of $H$. luederwaldti can lay more than one clutch of eggs in each breeding season, is the most likely to be correct.

No description of the vocalization of species of Holoaden had been published in the literature. Information on the emission of calls by species of Holoaden was reported by LuTz (1958), who noted that specimens of $H$. luederwaldti collected in Parque Nacional do Itatiaia and the Serra da Bocaina (= Holoaden sp.) emitted a cry when caught. The same behavior was reported for H. bradei (LuTz 1958). I did not observe, or record, this behavior for the specimens of $H$. luederwaldti caught in the PECJ It is possible that specimens emit this vocalization, probably a distress call (sensu BOGERT 1960), when they are manipulated in certain ways, but not in others. . The description of the advertisement call of $H$. luederwaldti given in this study will serve as a comparative basis for future studies with other species of Holoaden.

The record of a population of $H$. luederwaldti in the PECJ, after 40 years with no information on this species, indicates that we must survey different types of environments and diversify our sampling techniques. The record of $H$. luederwaldti was made possible by the use of pitfall traps, which have shown to be very efficient in recording species with cryptic habitats (often referred to as "rare"). The use of pitfall traps in anurofauna surveys has revealed new species records (e.g., Martins et al. 2006) and the 
rediscovery of species considered threatened (e.g., ZAHER et al. 2005, Brasileiro et al. 2008) highlighting the importance of using these traps to widen our knowledge about the distributional patterns of anurans.

The scarcity of information about the geographical distribution, natural history, and ecology of anurans in the Serra da Mantiqueira limits our knowledge of their diversity, population density and size of the area of occurrence of the various woodland species, hindering the development of adequate public policies for their conservation (Rossa-Feres et al. 2008). This situation has resulted in the compilation of controversial lists of threatened species (see PIMENTA et al. 2005), the great majority of which are considered data-deficient species, occasioning equivocal interpretations of the actual situation of different populations of Brazilian anurans.

\section{ACKNOWLEDGMENTS}

I would like to thank to Célio F.B. Haddad for his help and partnership during this project; Hussan E.D. Zaher for logistical support, and for permitting access to the specimens in the MZUSP collection; Felipe B.R. Gomes, Álvaro F.B. Junqueira, Pedro H. Bernardo, Ana Paula Suarez, and all the student interns of the Zoology Laboratory of UNITAU for their valuable contributions in the field activities; COTEC - Instituto Florestal and the direction of the Parque Estadual de Campos do Jordão for the authorization of this research (proc. \# 42.560/2003); IBAMA/RAN for the research permit (proc. \# 02010.005794/ 2003-65); and FAPESP for financial support for the research projects (Biota \# 01/13341-3 and JP. \# 06/56007-0).

\section{LITERATURE CITED}

Bogert, C.M. 1960. The influence of sound on the behavior of amphibians and reptiles, p. 137-320. In: W.W. LANYON \& W.N. TAVOLGA (Eds). Animal sounds and communication. Washington, DC, American Institute of Biological Sciences. 443p.

Brasileiro, C.A.; I.A. Martins \& J. Jim. 2008. Amphibia, Anura, Cycloramphidae, Odontophrynus moratoi: Distribution extension and advertisement call. Check List: Journal of Species Lists and Distribution 4 (4): 382-385.

Caramaschi, U. \& J.P. Pombal Jr. 2006. Notas sobre as séries-tipo de Holoaden bradei B. Lutz e Holoaden luederwaldti MirandaRibeiro (Anura, Brachycephalidae). Revista Brasileira de Zoologia 23 (4): 1261-1263.

Caramaschi, U.; A.M.P.T.C. Silva; S.P.C. Silva; E. Gouvea; E. Izecksohn; O.L. Peiхото \& J.P. Pombal-Jr. 2000. Anfíbios, p. 75-78. In: H.G. Bergallo; C.F.D Rocha; M.A.S. Alves \& M.V. Sluys (Eds). A Fauna Ameaçada de Extinção do Estado do Rio de Janeiro. Rio de Janeiro, Brasil. Rio de Janeiro, Editora da Universidade do Estado do Rio de Janeiro (EDUERJ), 166p.

Cruz, C.A.G. \& O.L. Рeixoto. 2004. Holoaden luederwaldti. In: IUCN 2008. IUCN Red List of Threatened Species. Available online at: www.iucnredlist.org[Accessed: 22/II/2009].
Frost, D. R. 2009. Amphibian species of the world: an online reference. Version 5.3. New York, American Museum of Natural History, available online at: http://research.amnh.org/ herpetology/amphibia [Accessed: 12/II/2009].

Haddad, C.F.B. 2005. Anfíbios, p. 59-63. In: A.B. Machado; C.S. Martins \& G.M. Drummond (Eds). Lista da Fauna Brasileira Ameaçada de Extinção. Belo Horizonte, Fundação Biodiversitas, 157p.

Haddad, C.F.B. \& C.P.A. Prado. 2005. Reproductive Modes in Frogs and Their Unexpected Diversity in the Atlantic Forest of Brazil. BioScience 55 (3): 207-217.

Hedges, S.B.; W.E. Duellman \& M.P. Heinicke. 2008. New World direct-developing frogs (Anura: Terrarana): Molecular phylogeny, classification, biogeography, and conservation. Zootaxa 1737: 1-182.

Heyer, W.R.; A.S. Rand; C.A.G. Cruz.; O.L. Peixoto \& C.E. NelSON. 1990. Frogs of Boracéia. Arquivos de Zoologia 31: 231410.

LuTz, B. 1958. Anfíbios novos e raros das serras costeiras do Brasil. Memórias do Instituto Oswaldo Cruz, Rio de Janeiro 56: 382-389.

Martins, I.A. \& J. JiM. 2003. Bioacoustic analysis of advertisement call in Hyla nana and Hyla sanborni in Botucatu, São Paulo, Brazil. Brazilian Journal of Biology 63: 507-516.

Martins, I.A.; F.B.R. Gomes; P.H. Bernardo \& A.P. Suarez. 2006. Geographic Distribution: Cycloramphus carvalhoi. Brasil, São Paulo. Herpetological Review 37 (1): 99.

Miranda-Ribeiro, A. 1920. Algumas considerações sobre Holoaden luederwaldti e gêneros correlatos. Revista Museu Paulista 12: 317-320.

Pimenta, B.V.S.; C.F.B. Haddad; L.B. Nascimento; C.A.G. Cruz \& J.P. Pombal JR. 2005. Comment on status and trends of amphibian declines and extinctions worldwide. Science 309 (5743): 1999b. doi: 10.1126/science.1112996.

Pombal JR, J.P.; C.C. Siqueira; T.A. Dorigo; D. Vrcibradic \& C.F.D. Rосна. 2008. A third species of the rare frog genus Holoaden (Terrarana, Strabomantidae) from a montane rainforest area of southeastern Brazil. Zootaxa 1938: 61-68.

Prado, J.B. \& M.M. Abreu. 1995. Aspectos geográficos do vale do Paraíba e município de Taubaté. Prefeitura municipal de Taubaté, Taubateana, \# 14, 276p.

Rossa-Feres, D.C.; M. Martins; O.A.V. Marques; I.A. Martins; R.J. SAWAYA \& C.F.B. HADDAD. 2008. Herpetofauna, p. 82-94. In: R.R. Rodrigues \& V.L.R. BONONI. (Eds). Diretrizes para conservação e restauração da biodiversidade no Estado de São Paulo. São Paulo, Imprensa Oficial do Estado de São Paulo, 248p.

São PAUlo. 2008. Secretaria do Meio Ambiente/Fundação Parque Zoológico. Decreto Estadual No. 53.494. Espécies da fauna silvestre ameaçadas, as quase ameaçadas, as colapsadas, sobrexplotadas, ameaçadas de sobrexplotação e com dados insuficientes para avaliação no estado de São Paulo. São Paulo, Imprensa Oficial, 9p. 
Wells, K.D. 2007. The ecology and behavior of amphibians. Chicago, The University of Chicago Press, 1148p.

Zaher, H.; E. Aguiar \& J.P. Pombal Jr. 2005. Paratelmatobius gaigeae (Cochran, 1938) re-discovered (Ampnhibia, Anura, Lepto-

Submitted: 23.IV.2009; Accepted: 23.I.2010.

Editorial responsibility: Fernando de Camargo Passos dactylidae). Arquivos do Museu Nacional, Rio de Janeiro 63 (2): 321-328.

ZAR, J.H. 1999. Biostatistical Analysis. New Jersey, PrenticeHall, $4^{\text {th }}$ ed. $663 p$. 